\title{
Marshall/Stickler syndrome
}

\author{
MICHAEL BARAITSER \\ From the Clinical Genetics Unit, The Hospital for Sick Children, Great Ormond Street, London WC1N 3JH
}

SUMmARY A family originally reported as a variant of Marshall syndrome is re-examined. The clinical picture now encompasses both the Marshall and Stickler syndromes and it is suggested that the distinction between the two should be abandoned.

New syndromes are described at such an alarming rate that it is prudent to reconsider their independent identity at regular intervals to exclude the possibility of the same syndrome acquiring different names. Such is the case with the Marshall and Stickler syndromes. It is still uncertain whether these are separate entities, but if the features of both are encompassed within a single pedigree then it is likely that they are manifestations of a single gene.

Patients with Marshall syndrome (not to be confused with the accelerated growth syndrome of the same name) have a short nose, anteverted nostrils, and flat malar bones. Deafness and cataract (but not retinal detachment) are common, whereas neither the Pierre Robin anomalad (small jaw, cleft palate, and glossoptosis) nor cleft palate alone are as frequent as in Stickler syndrome. Joint swelling (arthropathy) did not occur in any of the patients with Marshall syndrome tabulated by O'Donnell et $a l^{1}$ although short stature was a frequent manifestation. (See table 1 for a comparison of the two syndromes based on O'Donnell et al..$^{1}$ )

In 1972, Keith et al ${ }^{2}$ reported a family thought to be a variant of Marshall syndrome. Since then this family has been cited $^{3}$ as an example of Marshall syndrome and used to emphasise the difference between this and Stickler syndrome. Recently there has been an opportunity to re-examine the three affected members of the family described by Keith et al. ${ }^{2}$ The main features are shown in table 2 and the pedigree is shown in fig 1 .

The syndrome originally resembled Marshall syndrome (Stickler syndrome was not discussed), but was differentiated from it by the absence of cataracts and deafness in all three members of this family. Almost a decade later, case 2 (the proband's sister), now 8 years of age, has a sensorineural deafness and both case 1 and 2 have developed cataracts. Case 1 now has, in addition, a retinal detachment and is

Received for publication 20 July 1981 mentally handicapped. (fig 2). The radiological features in the proband are those of platyspondyly (maximal in the lumbar region), with flattening of the distal radial and ulnar epiphyses. These changes are well described in Stickler syndrome and have now been reported in Marshall syndrome. ${ }^{1}$

The affected family members at present have more features of the Marshall syndrome than they did in 1972 , but they also provide evidence to dispute the segregation of Marshall and Stickler syndromes as separate entities.

Cleft palate, retinal detachment, and joint swelling, all suggestive of Stickler syndrome, are

TABLE 1 Comparison of Marshall and Stickler syndromes, based on $O$ 'Donnell et al ${ }^{1}$

\begin{tabular}{lcc}
\hline & $\begin{array}{l}\text { Marshall } \\
\text { syndrome } \\
(n=20)\end{array}$ & $\begin{array}{l}\text { Stickler } \\
\text { syndrome } \\
(n=33)\end{array}$ \\
\hline Mental retardation & $\%$ & $\%$ \\
Deafness & 25 & 12 \\
Myopia & 80 & 18 \\
Cataract & 100 & 83 \\
Retinal detachment & 60 & 34 \\
Flat nasal bridge & 10 & 48 \\
Anteverted nostrils & 100 & 29 \\
Cleft palate alone & 100 & 0 \\
Pierre Robin anomalad & 5 & 31 \\
Arthropathy & 0 & 16 \\
Flat malar bones & 0 & 33 \\
Prominent upper incisors & 100 & 41 \\
\hline
\end{tabular}

TABLE 2 Main features of family of Keith et al ${ }^{2}$

\begin{tabular}{|c|c|c|c|c|}
\hline & $\begin{array}{l}\text { Case I } \\
\text { (boy) }\end{array}$ & $\begin{array}{l}\text { Case } 2 \\
\text { (girl) }\end{array}$ & $\begin{array}{l}\text { Case } 3 \\
\text { (mother) }\end{array}$ & $\begin{array}{l}\text { Marshall } \\
\text { syndrome }\end{array}$ \\
\hline Depressed nasal bridge & + & + & + & + \\
\hline Anteverted nostrils & - & + & + & + \\
\hline Wide-set eyes & $\div$ & $\div$ & + & + \\
\hline Myopia & + & $\div$ & + & + \\
\hline Cataracts & - & - & - & + \\
\hline Deafness & -- & - & - & + \\
\hline Short stature & + & + & $\div$ & + \\
\hline Cleft palate & + & - & - & - \\
\hline
\end{tabular}


I

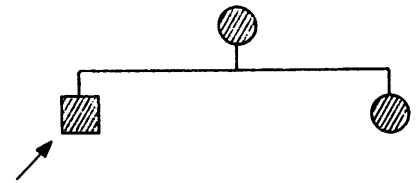

FIG 1 Family pedigree.

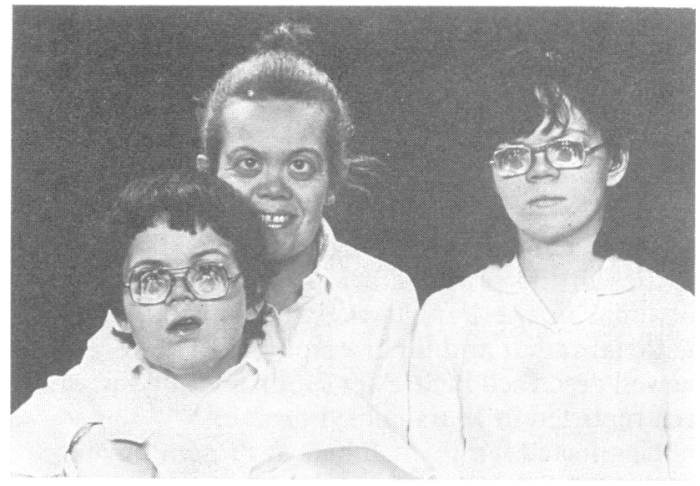

FIG 2 All three have a short nose, flat nasal bridge, anteverted nostrils, and myopia.

present in the proband. All three have a flat nasal bridge and short nose, but it can be seen in table 2 that these features occur in $30 \%$ of patients with Stickler syndrome (they occur in $100 \%$ of those with Marshall syndrome). Although it appears from table 1 as if anteverted nostrils do not occur in Stickler syndrome, even the girl in the picture shown by $\mathrm{Smith}^{4}$ in his book on recognisable malformation syndromes as a typical case of Stickler syndrome has anteverted nostrils. Only the calcification of the dura and the thickened calvarium remain as possible criteria for differentiating the two, but these findings are relatively non-specific and are unlikely to remain reliable discriminating signs.

Cohen ${ }^{5}$ suggested that it was time to put an end to the so-called Marshall syndrome and thought that all the signs could be encompassed within the category Stickler syndrome. Zellweger ${ }^{6}$ retorted that burial might be premature and stated that the skeletal lesions found in 40 to $50 \%$ of patients with Stickler syndrome were not found in Marshall syndrome (including the family reported by Keith et $^{\mathrm{al}} \mathrm{l}^{2}$ ). It is now clear that the skeletal changes are present in the family described by Keith et al and that the variation within the family is great enough for all the features to be explained by the pleiotropic action of a single gene. As pointed out by Zellweger, ${ }^{6}$ Marshall described his syndrome in 1958 and Stickler his in $1965 .{ }^{7}$ If it is now accepted that both described the same condition then the designation MarshallStickler is probably appropriate.

The patient was admitted under the care of Dr John Wilson whose permission to publish this report is gratefully acknowledged.

\section{References}

1 O'Donnell JJ, Sirkin S, Hall BD. Generalized osseous abnormalities in the Marshall syndrome. Birth Defects 1976 ;XII(5):299-314.

2 Keith CG, Dobbs RH, Shaw DG, Cottrall K. Abnormal facies, myopia and short stature. Arch Dis Child 1972;47: 787.

3 Zellweger H, Smith JK, Grutzner P. The Marshall syndrome: report of a new family. $J$ Pediatr 1974;84: 868-71.

4 Smith DW. Recognizable patterns of human malformation. Major problems in clinical pediatrics. Vol VII. Philadelphia: Saunders, 1976:238-9.

5 Cohen MM Jr. The demise of the Marshall syndrome. (Letter) J Pediatr 1974;85:878.

6 Zellweger H. Marshall syndrome: eulogy or resurrection? (Letter) J Pediatr 1975;86:817.

7 Stickler GB, Belau PG, Farrell FJ, et al. Hereditary progressive arthro-ophthalmology. Mayo Clin Proc $1965 ; 40: 433$.

Requests for reprints to Dr M Baraitser, Clinical Genetics Unit, The Hospital for Sick Children, Great Ormond Street, London WC1N 3JH. 